\title{
Hydrochemical and Stable Isotope Analyses Show Limited Interactions Between Groundwater and Lake Water in the Lake Bosomtwi Impact Crater, Ghana.
}

Yvonne Sena Akosua Loh

University of Ghana

Obed Fiifi Fynn ( $\sim$ obedfynn24@gmail.com )

WRI: Water Research Institute https://orcid.org/0000-0001-9338-6536

Evans Manu

GFZ German Research Center for Geoscience, Fluid Systems and Modeling, Telegrafenberg, 14473

Potsdam, Germany

George Yamoah Afrifa

University of Ghana

Millicent Obeng Addai

University of Education Winneba

Bismark Awinbire Akurugu

WRI: Water Research Institute

Sandow Mark Yidana

University of Ghana

\section{Research Article}

Keywords: Lake Bosumtwi, Stable Isotopes, Kinetic Fractionation, Surface Water, Groundwater, Ghana

Posted Date: January 11th, 2022

DOI: https://doi.org/10.21203/rs.3.rs-1093447/v1

License: (a) (1) This work is licensed under a Creative Commons Attribution 4.0 International License.

Read Full License 
1 HYDROCHEMICAL AND STABLE ISOTOPE ANALYSES SHOW LIMITED

2 INTERACTIONS BETWEEN GROUNDWATER AND LAKE WATER IN THE LAKE

3 BOSOMTWI IMPACT CRATER, GHANA.

4 Yvonne Sena Akosua Loh a , Obed Fiifi Fynn ${ }^{\text {b,*, Evans Manu }}{ }^{\text {b,c,d }}$, George Yamoah Afrifa a ,

5 Millicent Obeng Addai ${ }^{\text {e }}$, Bismark Awinbire Akurugu ${ }^{\mathrm{b}}$, Sandow Mark Yidana ${ }^{\mathrm{a}}$

$6 \quad{ }^{a}$ Department of Earth Science, University of Ghana, P. O. Box LG 58, Legon, Ghana

$7{ }^{b}$ Council for Scientific and Industrial Research, Water Research Institute, P. O. Box AH 38,

8 Accra, Ghana

$9{ }^{c}$ Germany Research Centre for Geosciences, Potsdam, Germany

$10{ }^{d}$ University of Potsdam, Potsdam, Germany

$11{ }^{e}$ Department of Geography Education, University of Education, Winneba, Winneba, Ghana

*Corresponding author's e-mail address: obedfynn24@gmail.com

Acknowledgements

17 We are grateful to the Office of Research, Innovation and Development (ORID), the

18 Department of Earth Science Capacity Building Project, University of Ghana and the

19 University of Rochester, New York. We are also grateful to the Ghana Geological Survey

20 Department for availing to us the accommodation facilities at Mmrontuo during the fieldwork.

21 We are greatly indebted to Profs. Asish Basu and Carmala Garzione and Dr. Penny Higgins,

22 all of the Department of Earth and Environmental Science, University of Rochester, for

23 allowing us to use their laboratories and helping with the analysis of the samples. 


\section{Abstract}

27 The relationship between groundwater and surface water in the Lake Bosumtwi impact crater

28 has been assessed using hydrochemical data and stable water isotopes of $\delta 18 \mathrm{O}$ and $\delta \mathrm{D}$. This

29 study aimed to define likely groundwater flow and recharge zones, estimate the rate of 30 evaporation, and examine the relationship between the lake and groundwater in the study area.

31 The results of Q-Mode hierarchical cluster analysis (HCA) clearly differentiate the lake water 32 from the groundwater based on their spatial relationship. These preliminary results indicated 33 that groundwater recharge occurs on the hilltops of the crater, where it is slightly acidic with

34 low levels of dissolved minerals, characterized by short residence time and rapid unrestricted 35 vertical infiltration and recharge. The groundwater becomes more mineralized with longer 36 contact times and deeper circulation with the host rock, while it flows from the recharge areas 37 towards the lake at lower elevations. Analyses of stable water isotopes of $\delta 18 \mathrm{O}$ and $\delta \mathrm{D}$ showed 38 a high evaporation rate on the lake surface, of $\sim 90 \%$ with a relatively significant evaporative 39 enrichment, whereas groundwater showed a relatively lower evaporation rate ranging between $4054-60 \%$. Both reservoirs do not appear to be hydraulically connected, and where such a 41 connection exists, it is expected to favour the lake.

42 Keywords: Lake Bosumtwi, Stable Isotopes, Kinetic Fractionation, Surface Water, 43 Groundwater, Ghana 


\section{Introduction}

49 Stable isotopes of hydrogen and oxygen are influenced by meteorological processes that

50 provide specific fingerprints as a basis for studying meteoric revolution of ordinary waters

51 within the water cycle. The investigation of environmental isotopes of natural waters has

52 proven in recent studies to be a relevant tool in the management and assessment of water resources. This enables deductions with regard to the recharge mechanism, identification of recharge and discharge areas, (Gopinath et al., 2021; Leketa and Abiye, 2021), aquifer interconnectivity and groundwater turnover time (IAEA, 1983; Chen et al., 2006; Doveri and Mussi, 2014) and to identify interactions between groundwater and surface water (Ojiambo et al., 2001; Zhang et al., 2016, Zhu et al., 2019; Leketa and Abiye, 2021).

These isotopes have equally been valuable in tracking the groundwater flow paths, evaluate residence time and aquifer discharge, identifying paleo waters, -- investigating water-rock

60 interactions (Abid et al., 2010; Pu et al 2020; Zhang et al., 2020; Zhou et al., 2021; Carreira et 61 al., 2021). For instance, Leketa and Abiye (2021) used stable isotopes of $\delta^{18} \mathrm{O}$ and $\delta \mathrm{D}$ to show 62 that recharge into the fractured quartzite aquifer of the Upper Crocodile River Basin occurs through direct mechanisms. Likewise, stable isotopes were used by Dogramaci et al. (2012), to evaluate the groundwater recharge in dry and semi-arid areas where high-intensity rain is supposed to control recharge. Sukhija et al. (2006) in their attempt to investigate recharge

66 mechanisms in a fractured competent rock aquifer with different weathered zone thicknesses

67 combined isotope and geochemical data and concluded that the groundwater route configuration is complex and involves multiple sources.

A combined application of multivariate statistical methods with graphical techniques for hydrogeochemical data interpretation (Guler et al., 2002; Helstrup et al., 2007; Yidana et al., 2012a; Loh et al., 2016; Dash \& Kalamdhad, 2021) has been helpful for the description of 
hydrochemical schemes and the delineation of groundwater flow paths. For instance, Yidana et al. (2012b) used hierarchical cluster analysis (HCA) in the Q-Mode to establish the spatial connection between groundwater hydrochemical datasets from the Ankobra Basin and led to the identification of three major spatial groundwater relationships based on the main of disparity in the hydrochemistry. In addition, Loh et al. (2012) used R-mode HCA of groundwater to identify the effects of both man-made and natural factors that control groundwater hydrochemistry. Using multivariate methods to understand the chemistry of groundwater, and specifically environmental isotopes, provides water managers and hydrogeologists with a powerful tool for solving water-related problems. This tool provides an understanding of geochemical routes and dynamics in hydrochemical groundwater studies.

Groundwater and surface water interactions play a critical role in the functioning of riparian ecology, and the occurrence of water quality problems in regional and sub-regional aquifers are well documented in recent times (Sophocleous, 2002; Di Ciacca, 2020; Kebede et al., 2021). In Ethiopia, Kebede et al. (2021) used stable isotopes of $\delta^{18} \mathrm{O}$ and $\delta \mathrm{D}$ to identify water loss from the Awash River. For the sustainable management of river basins, it is crucial to understand and measure interaction processes between groundwater and surface water. The exchanges between surface water in Lake Bosumtwi and the underlying aquifers has become a matter of passionate concern in recent years and has necessitated this study. Moreso, the wells situated along the crater rim are in close proximity to the lake and could obtain recharge from the lake. To further develop our understanding of the recharged dynamics in the aquifers surrounding the Lake, this study attempts to distinguish the isotopic signature of groundwater and lake water, identify possible recharge zones and groundwater flow paths, and outline potential geochemical transformation trends. 
95 In due course, the study will use hydrochemical and environmental isotope data of groundwater

96 and surface water to understand a possible hydraulic association between the lake and the

97 aquifer system near the former. The results of the study are expected to serve as a reference point and provide essential data and interpretations for understanding of groundwater recharge,

99 flow path and hydrochemical dynamics occurring within the Bosumtwi Impact Crater (BIC)

100 and its environs..

$101 \quad 2 . \quad$ Study Area

102 The study area, Lake Bosumtwi and its environs, is one of the major tourist sites in Ghana, 103 which attracts both leisure and educational visits. The Lake is close to Kumasi, the second 104 largest city in Ghana (Fig. 1). The climatic condition of the study area is akin to semi-equatorial 105 climate and characterized by two rainy seasons; major and minor rainy seasons. The major 106 rainy season begins in March, peaks in June and ends in July, whilst the minor season spans

107 September to November with a peak in October. Rainfall amounts range between $1.6 \mathrm{~m}$ and $1081.8 \mathrm{~m}$ per annum. On average, there are about 150 rainy days.

109 Temperatures range between $32^{\circ} \mathrm{C}$ in March and $20^{\circ} \mathrm{C}$ in August, with relative humidity 110 ranging between 70 and 80 per cent (Turner et al., 1996 a). Details of the hydrological 111 characteristics of the area are copiously discussed by other researchers (e.g., Turner et al., 1996;

112 Amu-Mensah et al., 2019)

113 Extensive farming, illegal mining and lumbering have changed the vegetation cover in the 114 study area from semi-deciduous and rainforest to mosaic secondary forest. Dendritic drainage 115 pattern is the drainage type pertaining to the area. However, around Lake Bosumtwi, there is 116 internal drainage where the streams flow from surrounding highlands into the Lake, forming a

117 dense network due to the double maxima rainfall regime. 
118 Lake Bosumtwi falls within the Birimian Supergroup of West Africa and made up of two major

119 lithostratigraphic units of early Proterozoic age, which are the Birimian Sedimentary Basins

120 and Birimian Volcanic Belts (Kesse, 1985; Karikari et al., 2007) (Fig. 1). Extensive studies by

121 various workers have established that these rocks host most of Ghana's mineral deposits such

122 as gold and diamond (Leube et al., 1990; Hirdes et al., 1992; Fougerouse et al., 2017; Kazapoe

$123 \&$ Arhin, 2021). These studies showed that the Eburnean tectonothermal event, which

124 stabilized the West African Craton, caused the Birimian Supracrustal rocks to become folded

125 and metamorphosed under greenschist-facies conditions, and intruded by granitoids. The

126 impact crater has a steep rim rising up to $300 \mathrm{~m}$ above present lake level. It is surrounded by

127 an irregular circular depression with a rim-to-rim diameter of $10.5 \mathrm{~km}$, as well as an outer ring

128 of minor topographic highs with a diameter of about $20 \mathrm{~km}$ (Jones et al., 1981; Reimold et al.,

129 1998). Rocks at and around Lake Bosumtwi are dominated by meta-sandstones, shales,

130 phyllites, and schist (Leube et al., 1990; Hirdes et al., 1992). These metasediments are rich in

131 quartz, feldspars and micas (biotite, muscovite).

132 The hydrogeology of the study area is characterized by the Birimian Province. Here the

133 hydrogeology is controlled by secondary porosity and permeability and extent of weathering.

134 These secondary porosity and permeability in the rocks of the study area were created during

135 the Eburnean orogeny that occurred about 2.1 Ga ago (Kesse, 1985) and impact cratering

136 (Reimold et al., 1998). Where there are tectonic lines of weakness as a result of the Eburnean

137 orogenic event, deep weathering of the rocks occurs in the study area. Weathering is enhanced

138 where the fractures, joints, faults, folds and quartz veins are extensive. Thick weathering zones

139 are known to be reservoirs for delivering huge volumes of water (Banoeng-Yakubo et al.,

140 2010). In some places, the weathered zones can be as thick as 137m (Kesse, 1985; Dapaah-

141 Siakwan and Gyau-Boakye 2000). In the Birimian Province, the lower part of the saprolite and

142 the upper part of the saprock forms the most productive section with regards to groundwater. 
143 These complement each other in terms of transmissivity and storage (Carrier et al., 2008). A

144 conceptual model developed by Carrier et al. (2008) shows that the hydrostratigraphy of the

145 Birimian Province starts with topsoil/laterite, followed by the saprolite then the saprock and 146 eventually the competent bedrock. Average aquifer transmissivity value in this Province is 7.4

$147 \mathrm{~m}^{2} / \mathrm{d}$ (Banoeng-Yakubo et al., 2011). Successful boreholes that have been drilled in this

148 Province suggest there is an average borehole yield of $12.7 \mathrm{~m} 3 / \mathrm{hr}$ (Banoeng-Yakubo et al., 149 2010; Dapaah-Siakwan and Gyau-Boakye 2000).

$150 \quad$ 3. Materials and Methods

151 Following conventional methods, water sampling was carried out over a generally cold and dry 152 period from late July to early August 2012. Thirty-four groundwater samples and seven lake water samples were collected in triplicate into $50 \mathrm{~mL}$ sterilized polypropylene tubes. Out of the three samples, two were filtered via a 0.45 -micron membrane. One of the filtered samples was subsequently acidified with nitric acid $\left(\mathrm{HNO}_{3}{ }^{-}\right)$to $\mathrm{pH}$ less than 2 for cation analysis, and

156 the other used for anion analysis. The $\delta^{18} \mathrm{O}$ and $\delta \mathrm{D}$ isotopes concentrations were determined using the third unfiltered sample. Physical parameters such as total dissolved solids (TDS), water temperature (T), salinity (Sal), electrical conductivity (EC), $\mathrm{pH}$, dissolved oxygen (DO) and oxidation-reduction potential (ORP) were measured in situ for all samples collected with

160 a HANNA Instruments $\mathrm{HI}$ 98280. In the field, the alkalinity (Alk) (as $\mathrm{HCO}_{3}{ }^{-}$) was measured

161 using a Hach digital titrator. Major cation and trace element concentrations were determined using an inductively coupled plasma-mass spectrometer (ICP-MS) at Activation Laboratories Ltd in Canada. Inductively coupled plasma optical emission spectrometry (ICP-OES) was then used to reanalyze samples that were over the required range (i.e., > $25 \mathrm{ppm}$ of $\mathrm{Na}, \mathrm{K}$, and $\mathrm{Sr}$;

165 and $>100 \mathrm{ppm}$ of $\mathrm{Ca}, \mathrm{Mg}$, and $\mathrm{Si})$. Anions of chloride $\left(\mathrm{Cl}^{-}\right)$, sulfate $\left(\mathrm{SO}_{4}{ }^{2-}\right)$, and nitrate $\left(\mathrm{NO}_{3}{ }^{-}\right.$

166 ), fluoride $(\mathrm{F})$, nitrite $\left(\mathrm{NO}_{2}^{-}\right)$, and phosphate $\left(\mathrm{PO}_{4}{ }^{3-}\right)$ were measured in milligram per liter $(\mathrm{mg} / \mathrm{l})$ 167 using a Dionex DX 120 ion chromatograph (I.C). 
168 Ten (10) rainfall samples collected in the months of April, May, June and July were analysed

169 for isotopes of $\delta^{18} \mathrm{O}$ and $\delta \mathrm{D}$. The Los Gatos Research Liquid Water Isotope Analyzer was used

170 to analyse these samples at the University of Rochester's Department of Earth and

171 Environmental Sciences. The findings were standardized (Coplen, 1994) on scales so that the

$172 \delta^{18} \mathrm{O}$ and $\delta \mathrm{DV}-\mathrm{SMOW}$ values were $0.0 \%$ and $0.0 \%$, respectively, whereas the $\delta 18 \mathrm{O}$ and $\delta \mathrm{D}$

173 values of SLAP were respectively $-428 \%$ and $-55.5 \%$. Unless otherwise stated, the 2-sigma

174 uncertainties for $\delta 18 \mathrm{O}$ and $\delta \mathrm{D}$ results were respectively $2.0 \%$ and $0.20 \%$. This suggests that

175 the result of isotopic analysis of the same sample would fall $95 \%$ of the time within the

176 uncertainty bounds if it were reanalysed.

177 Microsoft Excel and the statistical package for social sciences (SPSS) version 25.0 were

178 statistically used to conduct univariate, bivariate and multivariate analyses of the data sets

179 obtained. The multivariate statistical analyses were performed in order to constrain

180 relationships among multiple variables in the entire data set with emphasis on revealing

181 naturally, clusters/ groupings within the entire data, which on the contrary would not have been

182 noticed. In order to achieve optimal results from the statistical analysis, the normality of each

183 parameter was tested and those parameters which did not meet normality were transformed

184 accordingly. Log transformation was employed and then standardized to their respective $\mathrm{z}$ -

185 scores. In producing the spatial distribution maps, kriging was performed using different semi-

186 variogram models to determine the best model fit for the data set. Continuous adjustment was

187 made to the variogram parameters until all the criteria for an optimal model was arrived at. The

188 Gaussian model was the most accurate predictor for $\mathrm{pH}$ and EC data sets. The obtained

189 parameters $\left(C_{0}=0.00021 ; C_{0}+C=0.00654: A_{0}=0.03: r^{2}=0.786: R S S=1.056 E-05\right)$ from the

190 variogram model were then used to generate the spatial distribution maps of $\mathrm{pH}$ and $\mathrm{EC}$ in

191 ArcGIS version 10.7. 
192 Following the model advanced by Craig and Gordon (1965) and applied by Yidana et al.,

193 (2013), the surface evaporation rate from the Lake was estimated. This model determines the

194 fraction of water lost to evaporation $(f)$ (eqn 1).

$195 f=1-\left(\left(\delta_{L}-\delta^{*}\right) /\left(\delta_{P}-\delta^{*}\right)\right)^{\frac{1}{m}} ;$

$196 \delta^{*}=$ local limiting isotopic signature, which is determined from equation 2 :

$197 \delta^{*}=(h \delta A+\varepsilon) /\left(h-\frac{\varepsilon}{1000}\right)$

$198 \mathrm{~h}=$ average relative humidity of the study area,

$199 \delta \mathrm{A}=$ ambient air vapour isotope signature and

$200 \varepsilon=$ total isotope fractionation factor (Gat and Gonfiantini, 1981)

$201 \delta_{\mathrm{p}}$ and $\delta_{\mathrm{L}}$ represent the isotope signatures of the initial/source water for the lake and

202 sampled lake water respectively whiles $\mathrm{m}$, the index, is given by eqn. 3

$203 m=\left(h-\frac{\varepsilon}{1000}\right) /\left(1-h+\frac{\varepsilon_{k}}{1000}\right)$;

204 The isotopic kinetic fractionation factor, $\varepsilon_{k}$, is linked to the relative humidity between

205 water $(w)$ and water vapor (v) w.r.t $\delta^{18} \mathrm{O}$ (eqn. 4) (Gonfiantini, 1986).

206

$\varepsilon_{k}^{18} O_{w-v}=14.2(1-h) \% 0$

207 The $\varepsilon_{k}{ }^{18} O_{w-v}$ value of $4.26 \%$ was estimated at a local humidity of 0.7 (Turner et al., 208 1996a) for the lake water. 
$209 \varepsilon$ provides the sum of both equilibrium and non-equilibrium (kinetic) fractionation 210 factors in eqn. 5.

$211 \varepsilon=\varepsilon_{e q}+\varepsilon_{k}$

$212 \varepsilon_{e q}=10^{3}\left(1-\alpha^{18} O^{-1}{ }_{w-v}\right)$ and $\alpha^{18} O_{w-v}$, which is temperature (T measured in Kelvin)

213 dependent is expressed by eqn. 6 (Faure, 1998);

$21410^{3} \ln \alpha^{18} O_{w-v}=\left(\frac{1.534^{*} 10^{6}}{T^{2}}\right)-\left(\frac{3.206^{*} 10^{3}}{T}\right)+2.644$

215 For a mean annual $\mathrm{T}$ of $298.15 \mathrm{~K}\left(25^{\circ} \mathrm{C}\right), \varepsilon_{e q}$ returned a value of $9.11 \%$. The overall

216 enrichment under the prevailing conditions was $\varepsilon=\varepsilon_{e q}+=-13.37 \%$. Peng et al.

217 (2012) proposed that a relationship between $\delta_{I P}$ and $\delta \mathrm{A}$ presumes an isotopic 218 equilibrium (eqn. 7).

$219 \delta A \cong \delta_{I P}-10^{3}\left(\alpha_{w-v}-1\right)$

220 4. Results and Discussions

$2214.1 \quad$ Major ion chemistry

222 The summary statistics and distribution of hydrochemical parameters from the lake and 223 groundwater (GW) are presented in Fig. 2 and Table 1. The relative abundance of the major 224 cations in the lake occur in the order $\mathrm{Na}>>\mathrm{Mg}>\mathrm{K}>\mathrm{Ca}$, whilst in the groundwater, the cations 225 occur as $\mathrm{Ca} \geq \mathrm{Mg} \approx \mathrm{Na} \gg>\mathrm{K}$. The anions on the other hand occur in the order; $\mathrm{HCO}_{3}{ }^{-}>\mathrm{Cl}^{-} \approx$ $226 \mathrm{SO}_{4}{ }^{2-}>>\mathrm{NO}_{3}{ }^{-}$for groundwater and $\mathrm{HCO}_{3}{ }^{-}>\mathrm{Cl}^{-}>\mathrm{SO}_{4}{ }^{2-}>\mathrm{NO}_{3}{ }^{-}$for Lake water (Fig. 3a), 227 suggesting the dominance of meteoric waters. 
228 Hierarchical cluster analysis (HCA) performed on the hydrochemical parameters using Q229 mode, to discriminate samples based on their spatial relations resulted in four clusters, based 230 on a phenon line drawn at a linkage distance of 3 on the resultant dendrogram (Fig. 4). The 231 clusters are ordered from left to right, with clusters 1 to 3 being groundwater, and showing an increasing trend in ionic enrichment, whereas cluster 4 is composed of lake water samples.

233 Cluster 1 (C1) members, generally located in the SW on the top of the crater rim, in higher 234 elevations (about $308 \mathrm{~m}$ above sea level), exhibit relatively lower ionic content (median $\mathrm{EC}=$ $235188 \mu \mathrm{S} / \mathrm{cm}$ ), dominated by acidic waters (median $\mathrm{pH}=5.6$ ); characteristic of recharge zones 236 in the evolutionary sequence of groundwater flow regimes (Table 1; Figs. 5 a and b). The low mineralization also suggests short residence time and rapidly recharged groundwaters.

238 The relatively acidic waters observed in $\mathrm{C} 1$ members may have resulted from recharge from $239 \mathrm{CO}_{2}$-charged rainwater, and the dissolution of $\mathrm{CO}_{2}$ in the root zone as a result of plant and 240 animal respiration (Hem, 1985; Hasan and Tewari, 2020). 'Hard' rock and associated silicate 241 mineral dissolution is aided by acidic conditions as a result of low $\mathrm{pH}$, which explains the relatively high levels of $\mathrm{Si}$ in $\mathrm{C} 1$ members as compared to the other clusters as observed in Table 1. These processes cause the incongruent dissolution of mainly plagioclase, biotite and 244 potassium feldspar, which are common minerals identified in the underlying geology of the 245 study area (Garrels and Mackenzie, 1967; Dedzo et al., 2017).

246 Average concentration of the major ions used to plot a Schoeller diagram (Fig. 3b) 247 corroborated the evolutionary sequence observed above; $\mathrm{Na}^{+}$level is higher than $\mathrm{Mg}^{2+}$ and $248 \mathrm{Ca}^{2+}$ for $\mathrm{C} 1$ members. The dissolution of $\mathrm{Si}$ is enhanced under conditions of high $\mathrm{CO}_{2}$ and low $249 \mathrm{pH}$. Under such conditions, the groundwater gains high Si content over relatively short 250 residence time. And where the dissolution of plagioclase is present, a 2:1 $\mathrm{Si}$ to $\mathrm{Na}$ ratio is 251 expected (Garrels and Mackenzie, 1967; La Plante et al., 2021). This is consistent with the 
assertion that the high levels of $\mathrm{Si}$ in $\mathrm{C} 1$ members resulted from the aforementioned processes while $\mathrm{CO}_{2}$-charged meteoric waters recharged groundwater, and in the process dissolved a sodium rich plagioclase feldspar such as albite, which is common among the rocks of the study area. The weathering of silicate minerals such as albite is probably the cause of the high levels of $\mathrm{Na}^{+}$in $\mathrm{C} 1$ members. Samples from $\mathrm{C} 1$ are most likely groundwater collected from boreholes located in areas designated as potential recharge zones. The groundwater evolved from Cluster 1 to Clusters $2 \& 3$ as one moves down gradient towards relatively lower elevations in the NE. Cluster 2 (C2) members occur at elevations around $251 \mathrm{~m}$ asl, characterized by a high ionic $260(\mathrm{EC}=\mu \mathrm{S} / \mathrm{cm})$ content and a slightly acidic $(\mathrm{pH}=6.55)$ system. Cluster 2 appears to be the transmission zone members, which evolved into a more mineralized group (EC=888.5 $\mu \mathrm{S} / \mathrm{cm})$ in Cluster 3, located in a much lower elevation (163 m asl) with average $\mathrm{pH}$ of about 6.72 (Table 1 and Figs. 5 a and b). The relatively high mineralization in Cluster 3 members is attributable to the relatively longer residence time and increased interaction with aquifer materials as the groundwater transits and evolves from C1 to C3 (Freeze and Cherry, 1979; Stuyfzand, 1999; Appelo and Postma, 2005; Cochand et al., 2019; Ren et al., 2021). Although $\mathrm{C} 2$ and $\mathrm{C} 3$ appear to be equally balanced on the cations, with no particular cation dominating, $\mathrm{Ca}^{2+}$ appears to be the most abundant cation in most of the $\mathrm{C} 2$ and $\mathrm{C} 3$ members. While various studies (e.g. Hendry and Schwartz, 1990; Herczeg et al., 1993; Hiscock et al., 1996; Zhou et al., 2020; Mirzavand et al., 2020; Kumar et al., 2021) have employed major ion chemistry to ascertain the main sources of solutes and to better evaluate and understand groundwater evolution, several other studies (Panno et al., 1994; Gosselin et al., 2001; Stimson et al., 2001;

273 Pazand et al., 2018; Jeen et al., 2021) have demonstrated that the study of regional 274 hydrogeochemistry is valuable to the management of regional aquifers, tracing flow and 275 salinisation of groundwater. 
276 It can be observed from Table 1 that the Si levels decreases along the flow path as the 277 groundwater evolves, in the order; $\mathrm{C} 1>\mathrm{C} 2>\mathrm{C} 3$, suggesting possible crystallization of some 278 secondary mineral other than kaolinite that may have substituted silica in the groundwater 279 (Garrels and Mackenzie, 1967). Various factors such as aquifer mineralogy and characteristics, 280 climate and topography and recharge composition, (e.g., Guler et al., 2002; Loh et al., 2016;

281 Loh et al., 2020) which have been identified to influence the chemistry of groundwater, 282 collectively influence the diverse water types that change in time and space. The analyses and 283 observations made corroborates the assertion that hydrochemical facies analysis can be applied 284 to adequately delineate and trace potential groundwater recharge source(s). Hence it is cogent to conclude that the observed pattern is in tandem with the general hydrogeological principle that groundwater becomes relatively more mineralized, with increased resident and contact time with the aquifer material along its flow paths.

\subsection{Stable Isotopes}

289 Fig. 6 presents summary results of stable water isotopes $\left(\delta^{18} \mathrm{O}\right.$ and $\left.\delta^{2} \mathrm{H}\right)$ for rainwater (RW),

290 lake water (LW) and groundwater $(\mathrm{GW})$ from the study area. The results revealed that $\delta^{18} \mathrm{O}$ and $\delta^{2} \mathrm{H}$ values varied from $-3.6 \%$ to $-2.3 \%$ for $\delta^{18} \mathrm{O}$, and $-16.5 \%$ to $-7.6 \%$ for $\delta^{2} \mathrm{H}$ for the groundwater in the study area. Average $\delta^{18} \mathrm{O}$ values for the RW, LW and GW in the area are $4.47 \%$ o, $-3.06 \%$ and $4.74 \%$ respectively, whereas their respective average $\delta^{2} \mathrm{H}$ are $-25.49 \%$, $-12.46 \%$ and $23.98 \%$, although samples from the lake and rainfall were limited in number. Since water from natural water bodies such as rivers, lakes, dams, groundwater etc is derived from precipitation, its characteristic signatures in stable isotopes of ${ }^{18} \mathrm{O}$ and ${ }^{2} \mathrm{H}$ is expected to be evident in such water bodies in the study area. However, comparing the isotopic signatures of $\delta^{18} \mathrm{O}$ and $\delta^{2} \mathrm{H}$ for GW and LW to the precipitation in the study area, a progressive enrichment is observed in their isotope compositions, suggesting that the rainwater may have undergone some modification (Clark and Fritz, 1997). 
301 A biplot of $\delta^{2} \mathrm{H}$ against $\delta^{18} \mathrm{O}$ for the various water sources sampled in this study is presented in

302 Fig. 7. Rainfall event, RW04 which was sampled at the beginning of the rainy season, around

303 April is relatively isotopically enriched, compared to latter events in May to July, and exhibit

304 similar signature as groundwater in the areas. RW04 was particularly an early and light rainfall

305 event that commenced the rainy season. The enrichment of RW04 is attributable to the harsh

306 weather conditions associated with the onset of the rainy season; characterized by high

307 temperatures and evaporation rates (Fig. 7). The harsh weather conditions in the study area

308 lessens once the rainy season begins, leading to a much cooler environment, since the dry air

309 column and the ground gets saturated with water. This minimizes the evaporation rate and

310 subsequent enrichment of rainfall events (Fig 7) (Clark and Fritz, 1997).

311 To aid the discussions and further understanding of the relative isotopic enrichment or

312 depletion of the various water sources sampled in this study, the regression line established by

313 Akiti (1987) for the Accra plains was adopted as the LMWL (equation 8) due to the lack of

314 sufficient precipitation data. The LMWL as established by Akiti (1987) is comparable as a

315 result of the proximity and similar geographic and climatic conditions of Accra Plains to this

316 current study area. Although the intercept and slope of the regression lines may be different

317 depending on the prevailing local weather conditions (Hoefs, 2009; Lachniet et al., 2021; Smith

318 et al., 2021).

$319 \delta^{2} H=7.87 \delta^{18} O+13.6$

320 It can be observed in Fig. 7 that most of the samples from the rain and groundwater plot

321 between the LMWL (Akiti, 1987) and the GMWL, except for the LW samples, which plot far

322 below both MWLs. The level of departure of the samples from the MWLs reveals the degree

323 of relative enrichment. Samples that have undergone slight/no enrichment plot on/very close

324 to the MWLs, but where evaporative enrichment or mixing is significant, the samples depart 
325 from the MWLs, and fall to the right of the regression lines, with a relatively larger intercept 326 (Alley, 1993; Mazor, 1997). Hence GW samples that plotted close to the MWLs have not 327 undergone any significant evaporation and subsequently little/no enrichment occurred. This is 328 probably due to the fact that groundwater is generally protected from the impacts of high temperature and evaporation on the land surface. On the other hand, the lake, due to its

330 exposure to the harsh weather conditions is prone to high evaporation rates and subsequently 331 relatively high enrichment. This explains the departure of the lake samples from the MWLs 332 (Fig. 7).

333 A model proposed by Craig and Gordon (1965) has been adopted to estimate the rate of 334 evaporation from the lake surface. This model which has been adopted by several studies 335 (Dogramaci et al., 2012; Yidana, 2013; Gonfiantini et al., 2018; Dar et al., 2021) employed 336 average temperature in the area, slope of the local evaporation and the initial isotopic signature 337 of the precipitation to estimate evaporation rate for the lake. The isotopic signature of RW04 338 sampled in April was considered as the initial precipitation, and $\delta \mathrm{A}$ estimation resulted in $339 \quad 12.40 \%$ for $\delta^{18} \mathrm{O}$ using equation 7 . The resultant $\sim 90 \%$ evaporation rate for the lake surface 340 estimated is in tandem with the harsh climatic conditions that characterize the study area. This 341 further corroborates the assertion that water from the lake has undergone some intense 342 evaporation, and as a result it is isotopically enriched.

343 Equation 9 represents a regression line for $\mathrm{GW}$ in the study area, with a $\mathrm{r}=0.7$, indicating a 344 strong correlation. The slope and intercept in the regression line (eqn. 9) suggests that the 345 rainwater, prior to infiltration and recharge, may have undergone relative evaporative 346 enrichment, especially when compared with the LMWL and GMWL. This is in sync with what 347 has been reported in the literature about d-excess values of less than $10 \%$ (Dogramaci et al., 348 2012; Sreedevi et al., 2021). Based on Equation 9, the evaporation rate for the groundwater 
was estimated to range from $54-59.5 \%$, using $-17.03 \%$ and $-3.89 \%$ respectively as initial

$350 \delta^{2} \mathrm{H}$ and $\delta^{18} \mathrm{O}$ isotope contents. This suggests that evaporation is an active process in the unsaturated zone and possibly after recharge has occurred as observed in some studies in Ghana

352 (Addai et al., 2016; Akurugu et al., 2020). About more than half of the rainfall that transits the soil zone is lost to evaporation, suggesting that groundwater recharge probably largely results from vertical infiltration through fractures, implying less water availability as groundwater in the study area. The estimated initial value of $-3.89 \%$ for $\delta^{18} \mathrm{O}$ is comparable to the average $\delta^{18} \mathrm{O}$ values of $-4.47 \%,-3.20 \%,-3.10 \%$ obtained for the rainwater, Akiti (1987) and groundwater in the study area, which are characteristic of recent meteoric waters. This corroborates the claim that the groundwater may have been recharged through fissures and fractures by recent evaporated meteoric water.

360 Furthermore, it is evident in Figure 8a that the groundwater EC shows a general increasing

361 trend whereas the isotopic composition remains the same. This suggests that one of the main

362 factors influencing the hydrochemistry of the groundwater is rock mineralization and not 363 evaporation. Therefore, the isotopic signature as observed in the groundwater could only have 364 resulted from direct precipitation (Gibrilla et al., 2010).

366 Depletion gradients in stable water isotopes has been observed per $100 \mathrm{~m}$ rise in elevation, 367 ranging from -1 to $-4 \%$ for $\delta^{2} \mathrm{H}$ and -0.15 to $-0.6 \%$ for $\delta^{18} \mathrm{O}$ (Clark and Fritz, 1997; Dogramaci 368 et al., 2012). Groundwater samples in lower elevations and close to the lake were relatively 369 lighter in isotopic signatures than the lake water but common in isotopic content with samples 370 located around the crater rim; elevation difference of about $\sim 300 \mathrm{~m}$. This shows that the 371 isotopic contents of the various groundwater samples had no relationship with elevation in the 372 study area Fig. 8b; suggesting no seepage of water from the lake and groundwater. However, 
373 this does not exclude a possible hydraulic connection between the lake and shallow aquifers in

374 the study area.

375 Figure 8c shows the relationship between elevation and EC. It can be deduced that the EC of

376 the groundwater increases as one moves towards the lake in lower elevations, suggesting the

377 direction of groundwater flow is from the crater rim to the lake. Hence the claim that the crater

378 rim areas are the plausible recharge zones is in tandem with, results from the cluster analysis

379 (Fig. 4). Since the groundwater flows towards the lake, a detailed study may be required to

380 establish the possible connection between the lake and groundwater if any. This is important

381 to establish the impacts of low or high groundwater levels on the lake and vice versa, in the

382 wake of climate change impacts, land/cover change, population growth and urbanization.

\section{5. Conclusions}

384 Stable water isotopes of $\delta^{18} \mathrm{O}$ and $\delta \mathrm{D}$ as well as hydrochemical data from groundwater and lake

385 water from the Bosumtwi impact crater have been assessed. Results from the Q-mode HCA of the hydrochemical data distinguished four main clusters based on their spatial relation; uniquely discriminating the lake water from the groundwater. The Q-mode HCA also identifies hill tops of the crater as recharge zones, and as the groundwater moves downhill, it becomes more mineralized, influenced by the host rocks, as it evolves and flows towards the lake.

390 Vertical infiltration in the area is thought to occur rapidly through fractures, resulting in slightly evaporated recent meteoric waters recharging the groundwater. The stable water isotopes indicate that both groundwater and the lake water are considerably enriched relative to the local meteoric water, with the open lake water being even more so, due to its exposure to harsh

394 weather conditions on the surface. Evaporation rate of groundwater, which is thought to occur 395 during infiltration is estimated at 54-59.5\%, whereas evaporation over the Lake Bosumtwi surface is $\sim 90 \%$ based on $\delta 180$ and $\delta \mathrm{D}$ analysis, resulting in increased levels of univalent 
397 cations in the groundwater system. The preliminary results also suggest that any hydraulic 398 connection between the lake and groundwater may not be benefitting aquifers in the study area. 399 However, further studies are recommended to fully determine the extent of the hydraulic 400 connection between these two reservoirs.

401

402 Acknowledgements

403 Funding: This work has been partly supported by ORID, through the Faculty Development 404 Grant Award, the Department of Earth Science Capacity Building Project, University of Ghana 405 and the University of Rochester, New York. We are also grateful to the Ghana Geological 406 Survey Authority for availing their accommodation facilities at Mmrontuo during the 407 fieldwork. We are greatly indebted to Profs. Asish Basu and Carmala Garzione and Dr. Penny 408 Higgins, all of the Department of Earth and Environmental Science, University of Rochester, 409 for allowing us to use their laboratories and helping with the analysis of the samples. 


\section{References}

419 Abass, G., Shiloh, O., Tetteh T, A., Dickson, A., Samuel Y, G., Edward PK, B. and Alhassan, H., 2010. Origin of dissolve ions in groundwaters in the northern Densu River Basin of Ghana using stable isotopes of $18 \mathrm{O}$ and $2 \mathrm{H}$. Journal of water resource and protection, 2010.

Abid, K., Zouari, K. and Abidi, B., 2010. Identification and characterisation of hydrogeological relays of continental intercalaire aquifer of southern Tunisia. Carbonates and Evaporites, 25(1), pp.65-75.

Addai, M.O., Yidana, S.M., Chegbeleh, L., Adomako, D. and Banoeng-Yakubo, B., 2016. Groundwater recharge processes in the Nasia sub-catchment of the White Volta Basin:

Akiti, T.T., 1986. Environmental isotope study of ground water in crystalline rocks of the Accra plains (Ghana).

Akurugu, B. A., Chegbeleh, L. P., and Yidana, S. M., 2020. Characterisation of groundwater flow and recharge in crystalline basement rocks in the Talensi district, Northern Ghana.

Alley, W.M. ed., 1993. Regional ground-water quality. John Wiley \& Sons.

Amu-Mensah, F.K., Amu-Mensah, M.A., Akrong, M.O., Addico, G. and Darko, H., 2019. Hydrology of the major water sources of Lake Bosomtwe in Ghana. West African Journal of Applied Ecology, 27(1), pp 42-51. 
440 Banoeng-Yakubo, B., Yidana, S. M., Ajayi, J. O., Loh, Y., \& Asiedu, D. (2010). Hydrogeology and groundwater resources of Ghana: a review of the hydrogeology and hydrochemistry

Carreira, P.M., Marques, J.M., Guerra, A., Nunes, D., Marques, J.E., Teixeira, J. and Chaminé, H.I., 2021. Caldelas and Gerês hydrothermal systems (NW Portugal): a comparative study based on geochemical and isotopic signatures. Environmental Earth Sciences, 80(3), pp.1-20.

Cartwright, I., Hall, S., Tweed, S. and Leblanc, M., 2009. Geochemical and isotopic constraints on the interaction between saline lakes and groundwater in southeast Australia. Hydrogeology Journal, 17(8), p.1991.

Chen, Z., Nie, Z., Zhang, G., Wan, L. and Shen, J., 2006. Environmental isotopic study on the 451 recharge and residence time of groundwater in the Heihe River Basin, northwestern China. Hydrogeology Journal, 14(8), pp.1635-1651.

Clark, I.D. and Fritz, P., 1997. Environmental Isotopes in Hydrology Lewis Publishers. Boca 454 Raton, New York.

Cochand, M., Christe, P., Ornstein, P. and Hunkeler, D., 2019. Groundwater storage in high 456 alpine catchments and its contribution to streamflow. Water Resources Research, 55(4), pp.2613-2630.

Coplen, T.B., 1994. Reporting of stable hydrogen, carbon, and oxygen isotopic abundances 459 (technical report). Pure and applied chemistry, 66(2), pp.273-276. 
Dar, F.A., Jeelani, G., Perrin, J. and Ahmed, S., 2021. Groundwater recharge in semi-arid karst context using chloride and stable water isotopes. Groundwater for Sustainable Development, 14, p.100634.

Dash, S. and Kalamdhad, A.S., 2021. Hydrochemical dynamics of water quality for irrigation use and introducing a new water quality index incorporating multivariate statistics. Environmental Earth Sciences, 80(3), pp.1-21.

Dedzo, M.G., Tsozué, D., Mimba, M.E., Teddy, F., Nembungwe, R.M. and Linida, S., 2017. Importance of rocks and their weathering products on groundwater quality in CentralEast Cameroon. Hydrology, 4(2), p.23.

Di Ciacca, A., 2020. Spatially distributed recharge and groundwater-surface water interactions in groundwater models: from the field to the catchment scale.

Dogramaci, S., Skrzypek, G., Dodson, W. and Grierson, P.F., 2012. Stable isotope and hydrochemical evolution of groundwater in the semi-arid Hamersley Basin of subtropical northwest Australia. Journal of Hydrology, 475, pp.281-293.

Doveri, M. and Mussi, M., 2014. Water isotopes as environmental tracers for conceptual understanding of groundwater flow: An application for fractured aquifer systems in the “Scansano-Magliano in Toscana" area (Southern Tuscany, Italy). Water, 6(8), pp.22552277.

Fougerouse, D., Micklethwaite, S., Ulrich, S., Miller, J., Godel, B., Adams, D.T. and McCuaig, T.C., 2017. Evidence for two stages of mineralization in West Africa's largest gold deposit: Obuasi, Ghana. Economic Geology, 112(1), pp.3-22. 
481

Freeze, R.A. and Cherry, J.A., 1979. Groundwater. New Jersey: Prentice-Hall geochemical parameter distribution in a ground water system contaminated with petroleum hydrocarbons. Journal of Environmental Quality, 30, pp.1548-1563.

Garrels, R.M. and Mackenzie, F.T., 1967. Origin of the chemical compositions of some springs and lakes.

Gat, J.R. and Gonfiantini, R., 1981. Stable isotope hydrology. Deuterium and oxygen-18 in the water cycle.

Gonfiantini, R., 1986. Environmental isotopes in lake studies. Handbook of environmental isotope geochemistry, 2, pp.113-168.

Gonfiantini, R., Wassenaar, L.I., Araguas-Araguas, L. and Aggarwal, P.K., 2018. A unified Craig-Gordon isotope model of stable hydrogen and oxygen isotope fractionation during fresh or saltwater evaporation. Geochimica et Cosmochimica Acta, 235, pp.224236.

Gopinath, G., Resmi, T.R., Pragath, M., Jesiya, N.P., Hameed, A.S. and Deshpande, R.D., 2021. Isotopic differentiation of groundwater recharge processes in a semi-arid region of southern India. Environmental Earth Sciences, 80(16), pp.1-12.

Gosselin, D.C., Harvey, F.E. and Frost, C.D., 2001. Geochemical evolution of ground water in the Great Plains (Dakota) Aquifer of Nebraska: Implications for the management of a regional aquifer system. Groundwater, 39(1), pp.98-108.

Güler, C., Thyne, G.D., McCray, J.E. and Turner, K.A., 2002. Evaluation of graphical and multivariate statistical methods for classification of water chemistry data. Hydrogeology journal, 10(4), pp.455-474. 
503 Hasan, Z. and Tewari, D.D., 2020. Characteristics of Groundwater Quality in the Aquifer of Indo-Nepal Border of Balrampur City. INTERNATIONAL JOURNAL OF PLANT AND ENVIRONMENT, 6(02), pp.146-151.

Helstrup, T., Jørgensen, N.O. and Banoeng-Yakubo, B., 2007. Investigation of hydrochemical characteristics of groundwater from the Cretaceous-Eocene limestone aquifer in southern Ghana and southern Togo using hierarchical cluster analysis. Hydrogeology Journal, 15(5), pp.977-989.

Hem, J.D., 1985. Study and interpretation of the chemical characteristics of natural waters. US Geol. Survey Water Supply Paper 1473.

512 Hendry, M.J. and Schwartz, F.W., 1990. The chemical evolution of ground water in the Milk River aquifer, Canada. Groundwater, 28(2), pp.253-261.

Herczeg, A.L., Simpson, H.J. and Mazor, E., 1993. Transport of soluble salts in a large semiarid basin: River Murray, Australia. Journal of Hydrology, 144(1-4), pp.59-84.

516 Hirdes, W., Davis, D.W. and Eisenlohr, B.N., 1992. Reassessment of Proterozoic granitoid ages in Ghana on the basis of $\mathrm{U} / \mathrm{Pb}$ zircon and monazite dating. Precambrian Research, 56(1-2), pp.89-96.

Hiscock, K.M., Dennis, P.F., Saynor, P.R. and Thomas, M.O., 1996. Hydrochemical and stable isotope evidence for the extent and nature of the effective Chalk aquifer of north Norfolk, UK. Journal of Hydrology, 180(1-4), pp.79-107.

522 Hoefs, J. and Hoefs, J., 2009. Stable isotope geochemistry (Vol. 285). Berlin: springer.

523 IAEA, 1983. Guidebook on Nuclear Techniques in hydrology. Vienna: IAEA, 91. 
Jeen, S.W., Kang, J., Jung, H. and Lee, J., 2021. Review of Seawater Intrusion in Western Coastal Regions of South Korea. Water, 13(6), p.761.

Jones, W.B., Bacon, M. and Hastings, D.A., 1981. The Lake Bosumtwi impact crater, Ghana. Geological Society of America Bulletin, 92(6), pp.342-349.

Karikari, F., Ferriere, L., Koeberl, C., Reimold, W.U. and Mader, D., 2007. Petrography, geochemistry, and alteration of country rocks from the Bosumtwi impact structure, Ghana. Meteoritics \& Planetary Science, 42(4-5), pp.513-540.

Kazapoe, R. and Arhin, E., 2021. Determination of local background and baseline values of elements within the soils of the Birimian Terrain of the Wassa Area of Southwest Ghana. Geology, Ecology, and Landscapes, 5(3), pp.199-208.

Kebede, S., Charles, K., Godfrey, S., MacDonald, A. and Taylor, R.G., 2021. Regional-scale interactions between groundwater and surface water under changing aridity: evidence from the River Awash Basin, Ethiopia. Hydrological Sciences Journal, 66(3), pp.450463.

Kesse, G.O., 1985. The mineral and rock resources of Ghana.

Kumar, S., Joshi, S.K., Pant, N., Singh, S., Chakravorty, B., Saini, R.K., Kumar, V., Singh, A., Ghosh, N.C., Mukherjee, A. and Rai, P., 2021. Hydrogeochemical evolution and groundwater recharge processes in arsenic enriched area in central Gangetic plain, India. Applied Geochemistry, 131, p.105044.

La Plante, E.C., Simonetti, D.A., Wang, J., Al-Turki, A., Chen, X., Jassby, D. and Sant, G.N., 2021. Saline Water-Based Mineralization Pathway for Gigatonne-Scale CO2 Management. ACS Sustainable Chemistry \& Engineering, 9(3), pp.1073-1089. 
546 Lachniet, M.S., Moy, C.M., Riesselman, C., Stephen, H. and Lorrey, A.M., 2021. Climatic and topographic control of the stable isotope values of rivers on the South Island of New Zealand. Paleoceanography and Paleoclimatology, p.e2021PA004220.

Leketa, K. and Abiye, T., 2021. Using Environmental Tracers to Characterize Groundwater Flow Mechanisms in the Fractured Crystalline and Karst Aquifers in Upper Crocodile River Basin, Johannesburg, South Africa. Hydrology, 8(1), p.50.

Leube, A., Hirdes, W., Mauer, R. and Kesse, G.O., 1990. The early Proterozoic Birimian Supergroup of Ghana and some aspects of its associated gold mineralization. Precambrian research, 46(1-2), pp.139-165.

Loh, Y.S., Banoeng-Yakubo, B., Yidana, S.M., Asiedu, D., Akabzaa, T. and Jørgensen, N.O., 2012. Hydrochemical characterisation of groundwater in parts of the Volta Basin, Northern Ghana. Ghana Mining Journal, 13, pp.24-32.

Loh, Y.S.A., Akurugu, B.A., Manu, E. and Aliou, A.S., 2020. Assessment of groundwater quality and the main controls on its hydrochemistry in some Voltaian and basement aquifers, northern Ghana. Groundwater for Sustainable Development, 10, p.100296.

Loh, Y.S.A., Yidana, S.M., Banoeng-Yakubo, B., Sakyi, P.A., Addai, M.O. and Asiedu, D.K., 2016. Determination of the mineral stability field of evolving groundwater in the Lake Bosumtwi impact crater and surrounding areas. Journal of African Earth Sciences, 121,

Mazor, E., 1997. Chemical and isotopic groundwater hydrology: the applied approach (No. Ed. 2). Marcel Dekker Inc.. 
Mirzavand, M., Ghasemieh, H., Sadatinejad, S.J. and Bagheri, R., 2020. An overview on source, mechanism and investigation approaches in groundwater salinization studies. International Journal of Environmental Science and Technology, 17(4),

Ojiambo, B.S., Poreda, R.J. and Lyons, W.B., 2001. Ground water/surface water interactions 572 in Lake Naivasha, Kenya, Using $\delta 18 \mathrm{O}, \delta \mathrm{D}$, and $3 \mathrm{H} / 3 \mathrm{He}$ agedating. Groundwater, 39(4), pp.526-533.

574

575

576

577

578

579

580

581

582

583

584

585

586

587

588 pp.2463-2476.

Panno, S.V., Hackley, K.C., Cartwright, K. and Liu, C.L., 1994. Hydrochemistry of the Mahomet Bedrock Valley Aquifer, east-central Illinois: Indicators of recharge and ground-water flow. Groundwater, 32(4), pp.591-604.

Pazand, K., Khosravi, D., Ghaderi, M.R. and Rezvanianzadeh, M.R., 2018. Identification of the hydrogeochemical processes and assessment of groundwater in a semi-arid region using major ion chemistry: A case study of Ardestan basin in Central Iran. Groundwater for Sustainable Development, 6, pp.245-254.

Peng, T.R., Huang, C.C., Wang, C.H., Liu, T.K., Lu, W.C. and Chen, K.Y., 2012. Using oxygen, hydrogen, and tritium isotopes to assess pond water's contribution to groundwater and local precipitation in the pediment tableland areas of northwestern Taiwan. Journal of Hydrology, 450, pp.105-116.

Pu, H., Song, W. and Wu, J., 2020. Using Soil Water Stable Isotopes to Investigate Soil Water Movement in a Water Conservation Forest in Hani Terrace. Water, 12(12), p.3520.

Reimold, W.U., Brandt, D. and Koeberl, C., 1998. Detailed structural analysis of the rim of a large, complex impact crater: Bosumtwi crater, Ghana. Geology, 26(6), pp.543-546. 
Ren, X., Li, P., He, X., Su, F. and Elumalai, V., 2021. Hydrogeochemical processes affecting groundwater chemistry in the central part of the Guanzhong Basin, China. Archives of Environmental Contamination and Toxicology, 80(1), pp.74-91.

Smith, D.F., Saelens, E., Leslie, D.L. and Carey, A.E., 2021. Local meteoric water lines describe extratropical precipitation. Hydrological Processes, 35(2), p.e14059.

Sophocleous, M., 2002. Interactions between groundwater and surface water: the state of the science. Hydrogeology journal, 10(1), pp.52-67.

Sreedevi, P.D., Sreekanth, P.D. and Reddy, D.V., 2021. Deuterium Excess of Groundwater as a Proxy for Recharge in an Evaporative Environment of a Granitic Aquifer, South India. Journal of the Geological Society of India, 97(6), pp.649-655.

Stimson, J., Frape, S., Drimmie, R. and Rudolph, D., 2001. Isotopic and geochemical evidence of regional-scale anisotropy and interconnectivity of an alluvial fan system,

Stuyfzand, P.J., 1999. Patterns in groundwater chemistry resulting from groundwater 603 flow. Hydrogeology Journal, 7(1), pp.15-27.

604

Sukhija, B.S., Reddy, D.V., Nagabhushanam, P., Bhattacharya, S.K., Jani, R.A. and Kumar, 605 D., 2006. Characterisation of recharge processes and groundwater flow mechanisms in weathered-fractured granites of Hyderabad (India) using isotopes. Hydrogeology Journal, 14(5), pp.663-674. Bosumtwi, a hydrologically closed basin in the humid zone of tropical 
611 Yidana, S.M., 2013. The stable isotope characteristics of groundwater in the Voltaian BasinAn evaluation of the role of meteoric recharge in the basin. Journal of Hydrogeology

614 Yidana, S.M., Banoeng-Yakubo, B. and Sakyi, P.A., 2012a. Identifying key processes in the and Hydrol. Eng, 2, p.2.

617 Yidana, S.M., Ophori, D., Banoeng-Yakubo, B. and Samed, A.A., 2012b. A factor model to explain the hydrochemistry and causes of fluoride enrichment in groundwater from the middle Voltaian sedimentary aquifers in the northern region, Ghana.

620

621

622

623

624

625

626

627

628

629

630

631

632 hydrochemistry of a basin through the combined use of factor and regression models. Journal of earth system science, 121(2), pp.491-507.

Zhang, B., Song, X., Zhang, Y., Ma, Y., Tang, C., Yang, L. and Wang, Z.L., 2016. The interaction between surface water and groundwater and its effect on water quality in the Second Songhua River basin, northeast China. Journal of Earth System Science, 125(7), pp.1495-1507.

Zhang, Q., Luo, Z., Lu, W., Harald, Z., Zhao, Y. and Tang, J., 2020. Using water isotopes and hydrogeochemical evidences to characterize groundwater age and recharge rate in the Zhangjiakou area, North China. Journal of Geographical Sciences, 30, pp.935-948.

Zhou, J., Liu, G., Meng, Y., Xia, C., Chen, K. and Chen, Y., 2021. Using stable isotopes as tracer to investigate hydrological condition and estimate water residence time in a plain region, Chengdu, China. Scientific reports, 11(1), pp.1-12.

Zhou, Y., Li, P., Xue, L., Dong, Z. and Li, D., 2020. Solute geochemistry and groundwater quality for drinking and irrigation purposes: a case study in Xinle City, North China. Geochemistry, 80(4), p.125609. 
633 Zhu, M., Wang, S., Kong, X., Zheng, W., Feng, W., Zhang, X., Yuan, R., Song, X. and 634 Sprenger, M., 2019. Interaction of surface water and groundwater influenced by groundwater over-extraction, waste water discharge and water transfer in Xiong'an

\section{STATEMENT AND DECLARATION}

639 Funding: This work has been partly supported by the Office of Research, Innovation and

640 Development (ORID), through the Faculty Development Grant Award of the University of

641 Ghana, Ghana and the Rochester International Council Fellowship for Doctoral Thesis

642 Completion, University of Rochester, New York.

643 Competing Interest: The authors declare that they have no known competing financial 644 interests or personal relationships that could have appeared to influence the work reported in 645 this paper.

646

647 AUTHOR CONTRIBUTIONS

648 Yvonne Sena Akosua Loh: Conceptualization, Methodology, Data curation, Writing-original 649 draft, Visualization, Funding acquisition. Obed Fiifi Fynn: Formal analysis, Investigation, 650 Visualization. Bismark Awinbire Akurugu: Methodology, Writing-review and editing. 651 George Yamoah Afrifa: Writing-review and editing, Investigation, Resources. Millicent 652 Obeng Addai: Investigation, Validation. Evans Manu: Writing-review and editing, 653 Investigation, Resources. Sandow Mark Yidana: Conceptualization, Writing-review and 654 editing, Supervision, Project administration, Funding acquisition. 
Figures

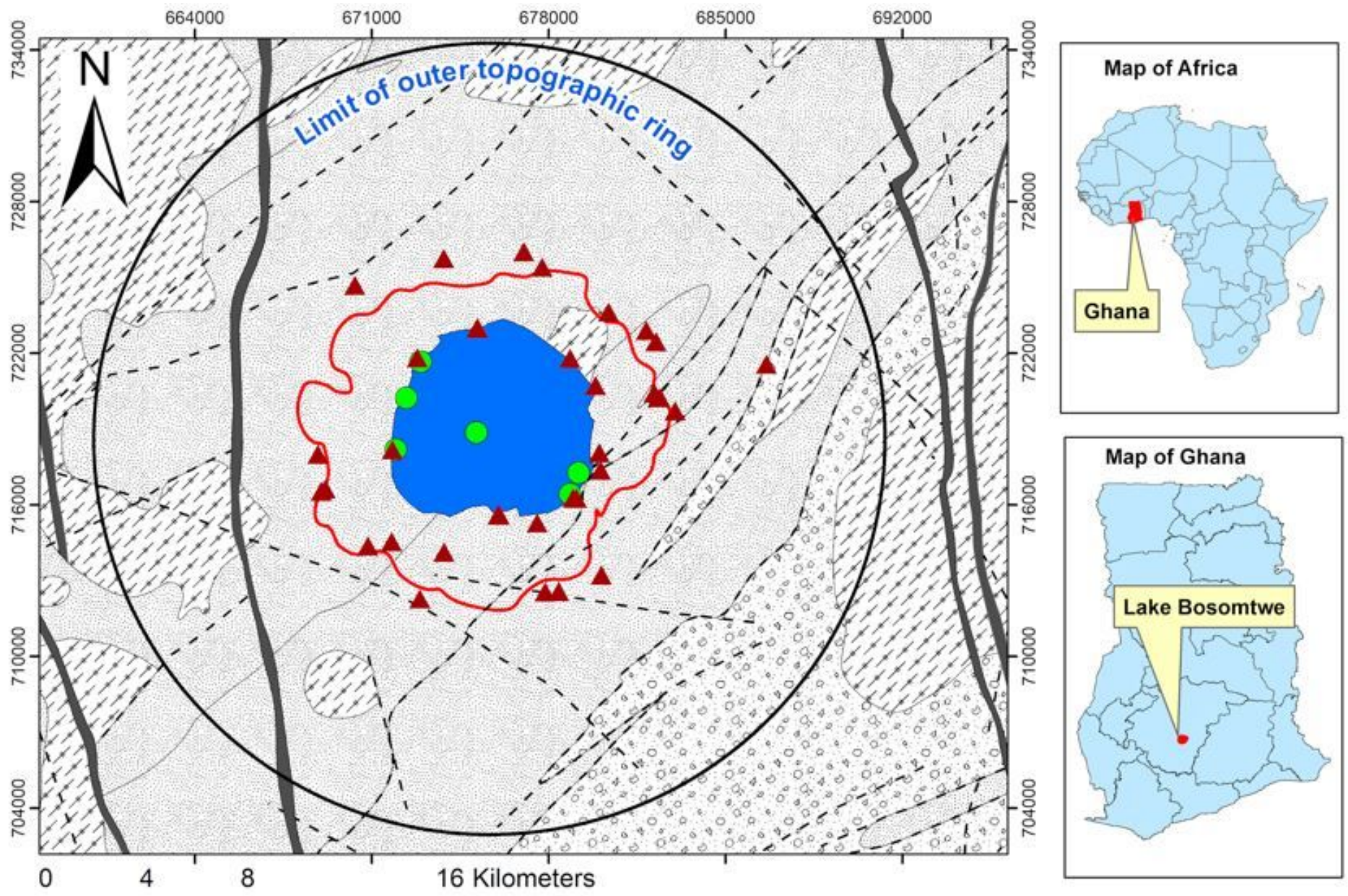

\section{Legend}

-.-- Fault

- Groundwater

- Lake water

C Crater Rim

Lake Bosomtwe

\section{Geology}

Birimian Supergroup;

Metavolcanics, metasediments; altered

intrusives, basalt and spilitic basalt, phyllite,

metagreywacke, shales, schist
Tarkwaian Group;

Banket member quartzite, conglomerate, sandstone

23 Eburnean Plutonic Suite;

Biotite granitoid, hornblende-biotite tonalite, muscovite granite, granodiorite

Dyke;

Mafic dyke, dolerite, may include pre-Mesozoic dyke

\section{Figure 1}

Geological map of the study area showing sample points 


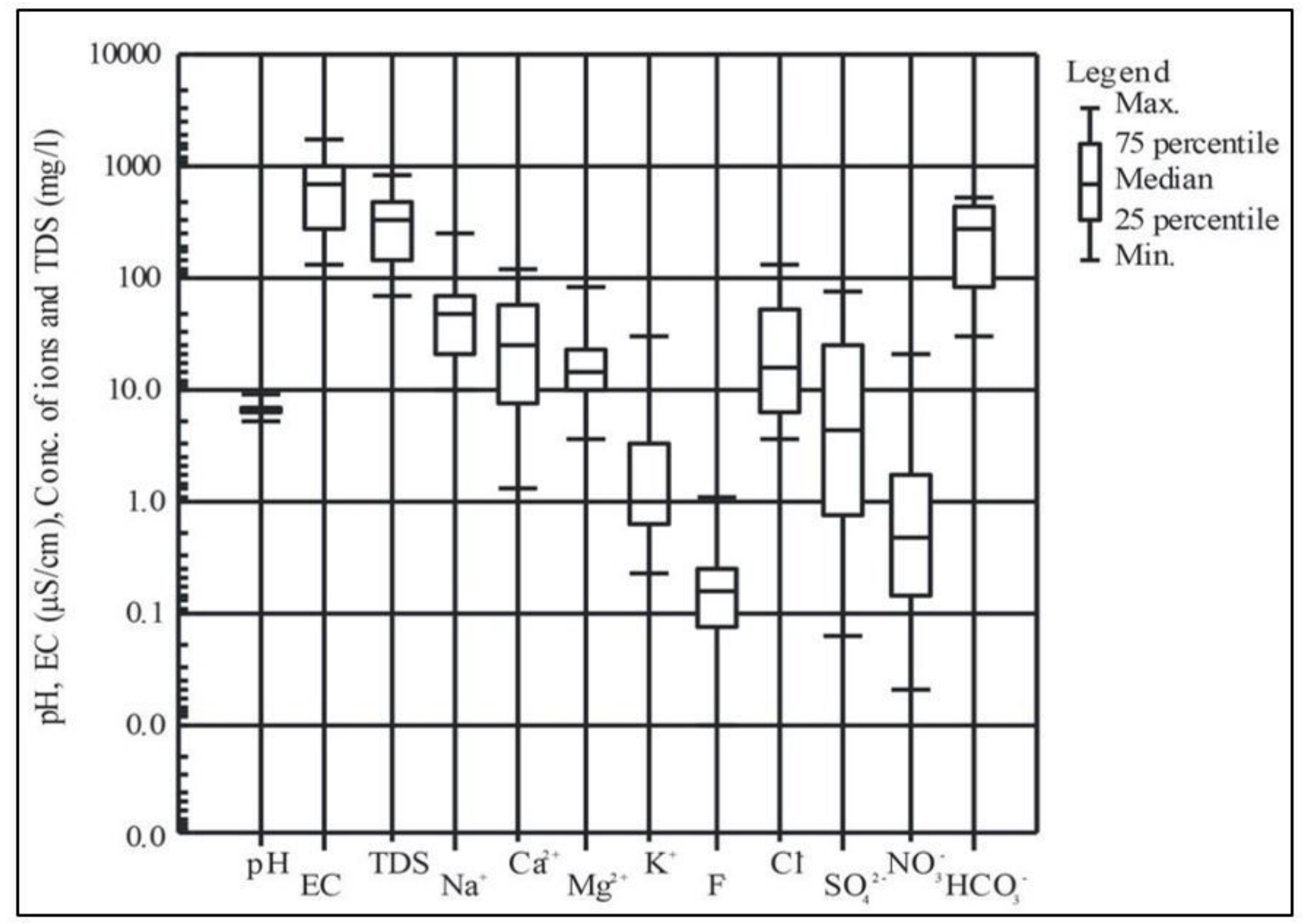

Figure 2

Box plot for the physical and major ions for the water samples from the study area 


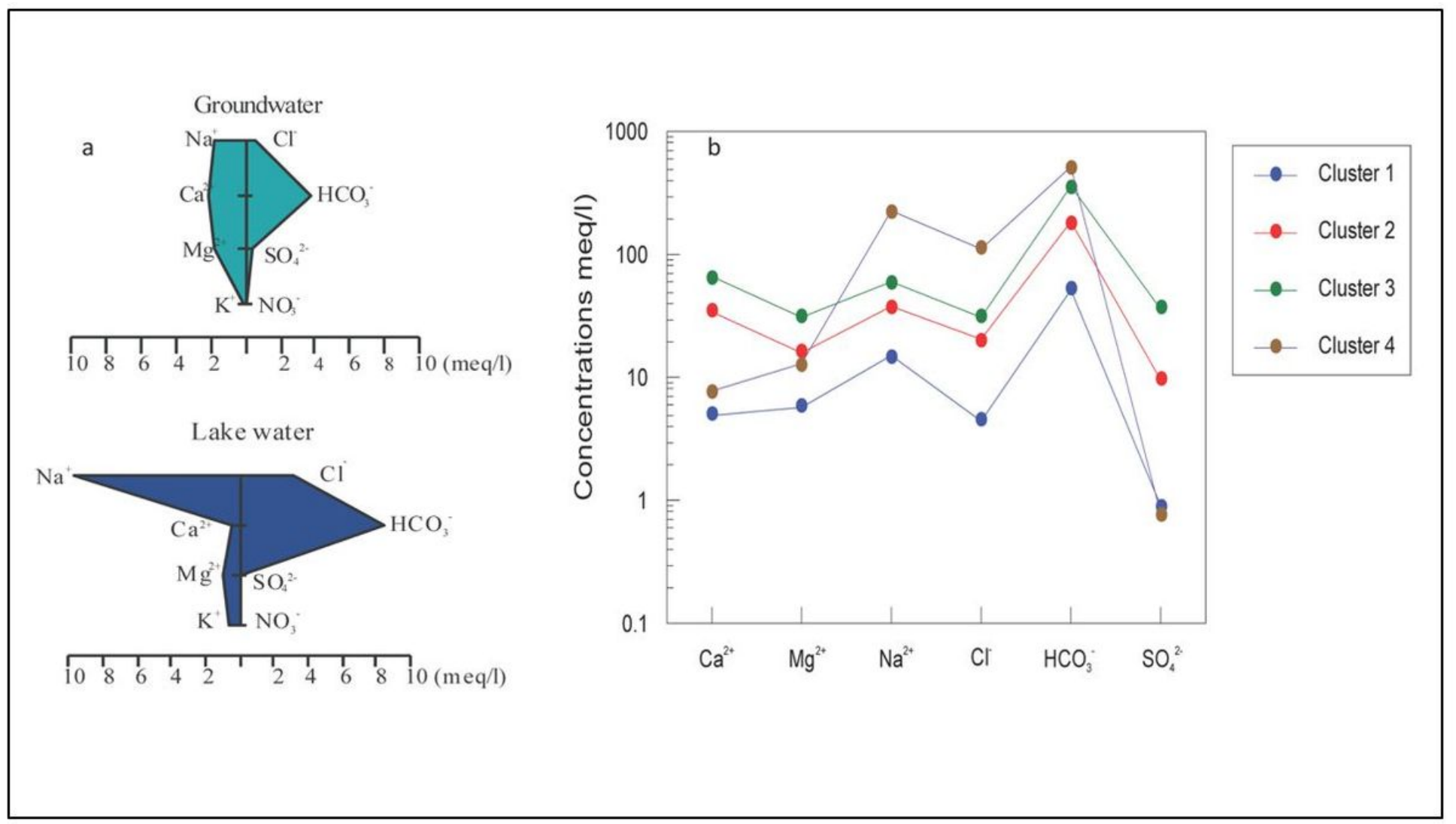

Figure 3

$a$ and $b$ : Stiff diagrams for the mean concentration of the major ions in groundwater/ lake water and Schoeller diagram showing the arithmetic mean of the major ions in each cluster 


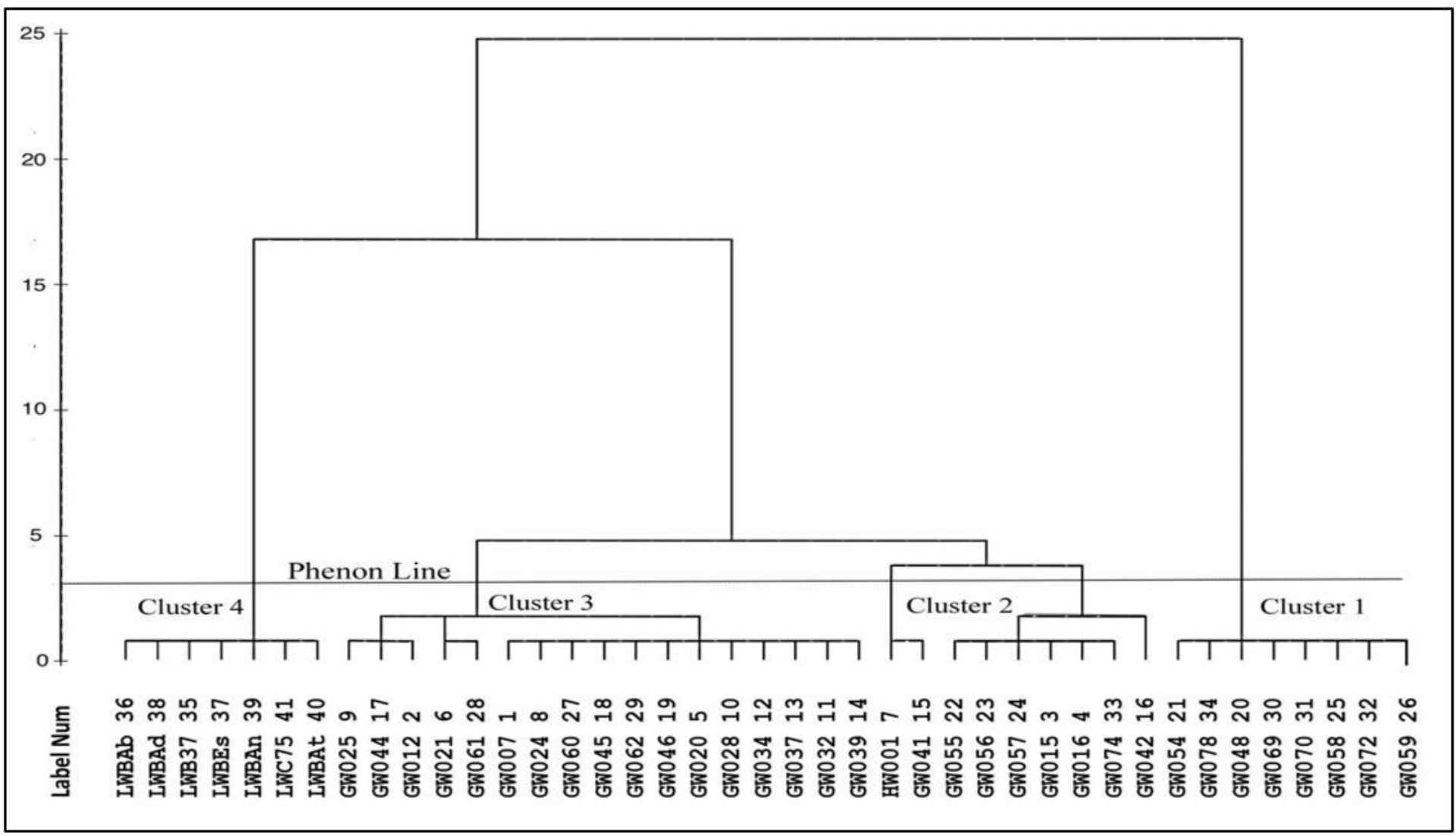

Figure 4

Dendrogram generated from HCA of hydrochemical data from groundwater and lake water showing associations between the samples 


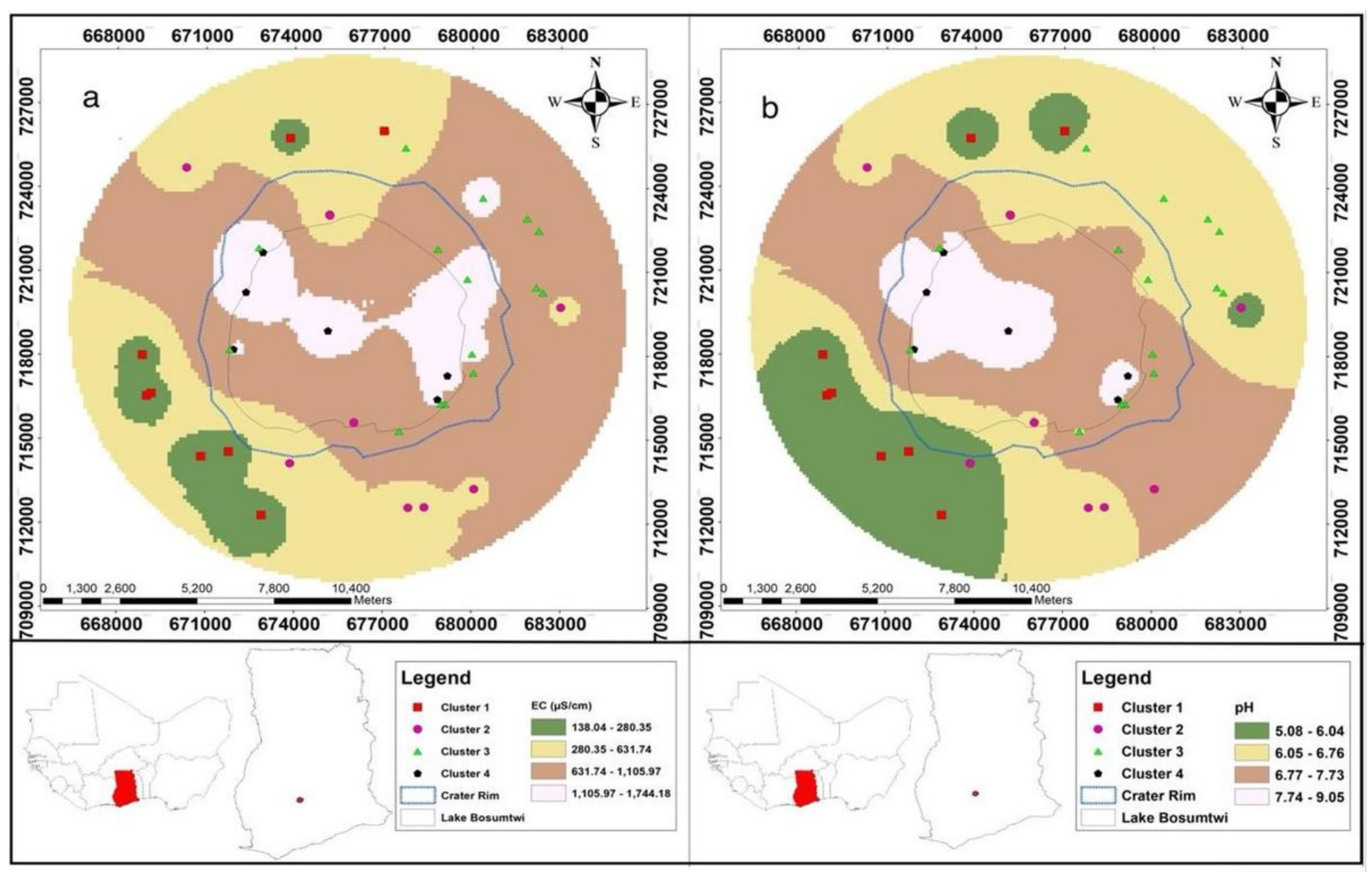

Figure 5

$\mathrm{a}$ and $\mathrm{b}$ : Spatial distribution of $\mathrm{EC}(\mu \mathrm{S} / \mathrm{cm})$ and $\mathrm{pH}(\mathrm{pH}$ units) in relation to sample clusters 


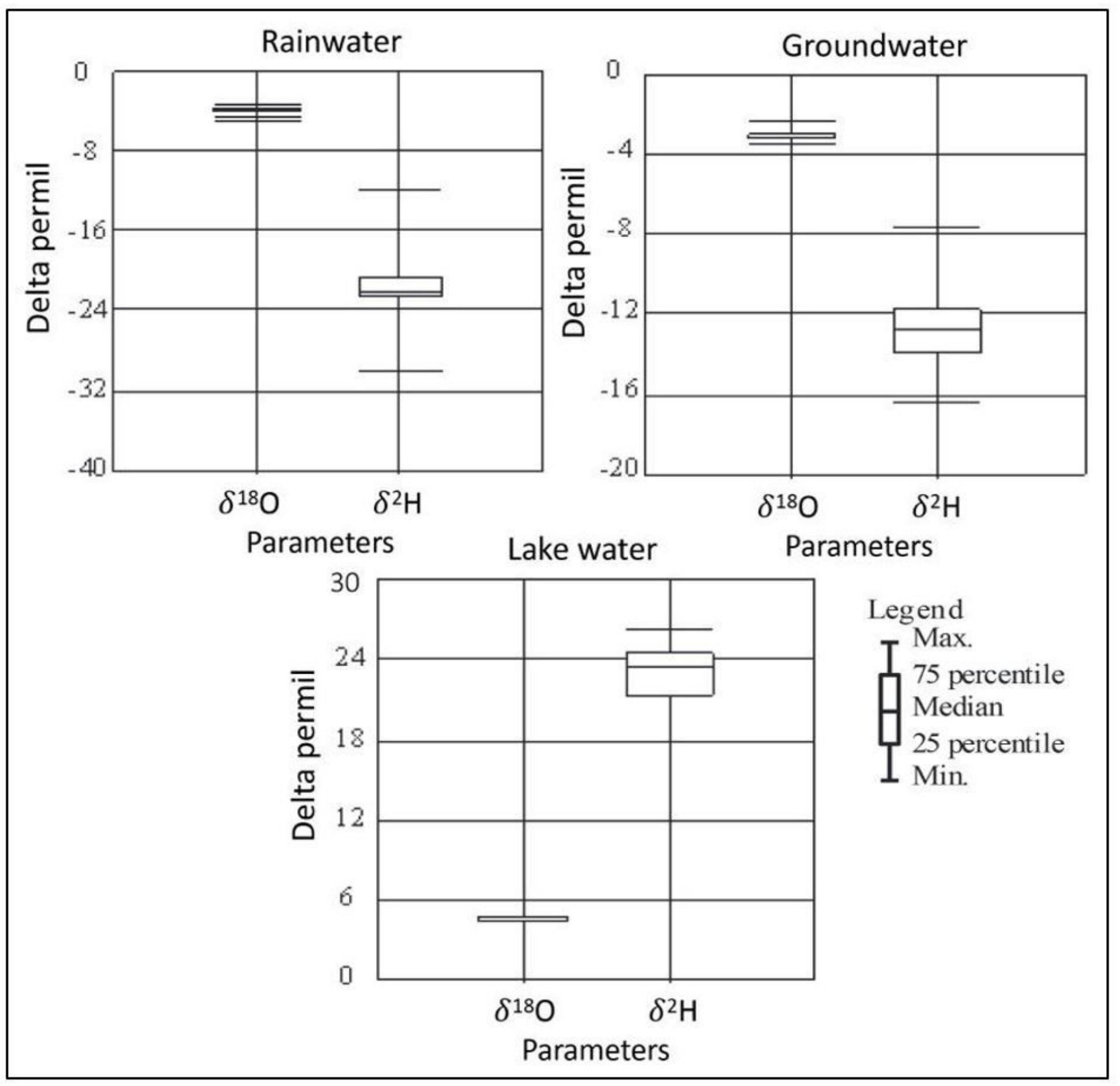

Figure 6

Box plot of the stable isotope contents of the analysed water samples 
- Groundwater

- Lake Water

A Rain Water

— Linear (GMWL)

- - - Linear (LMWL (Akiti, 1987))

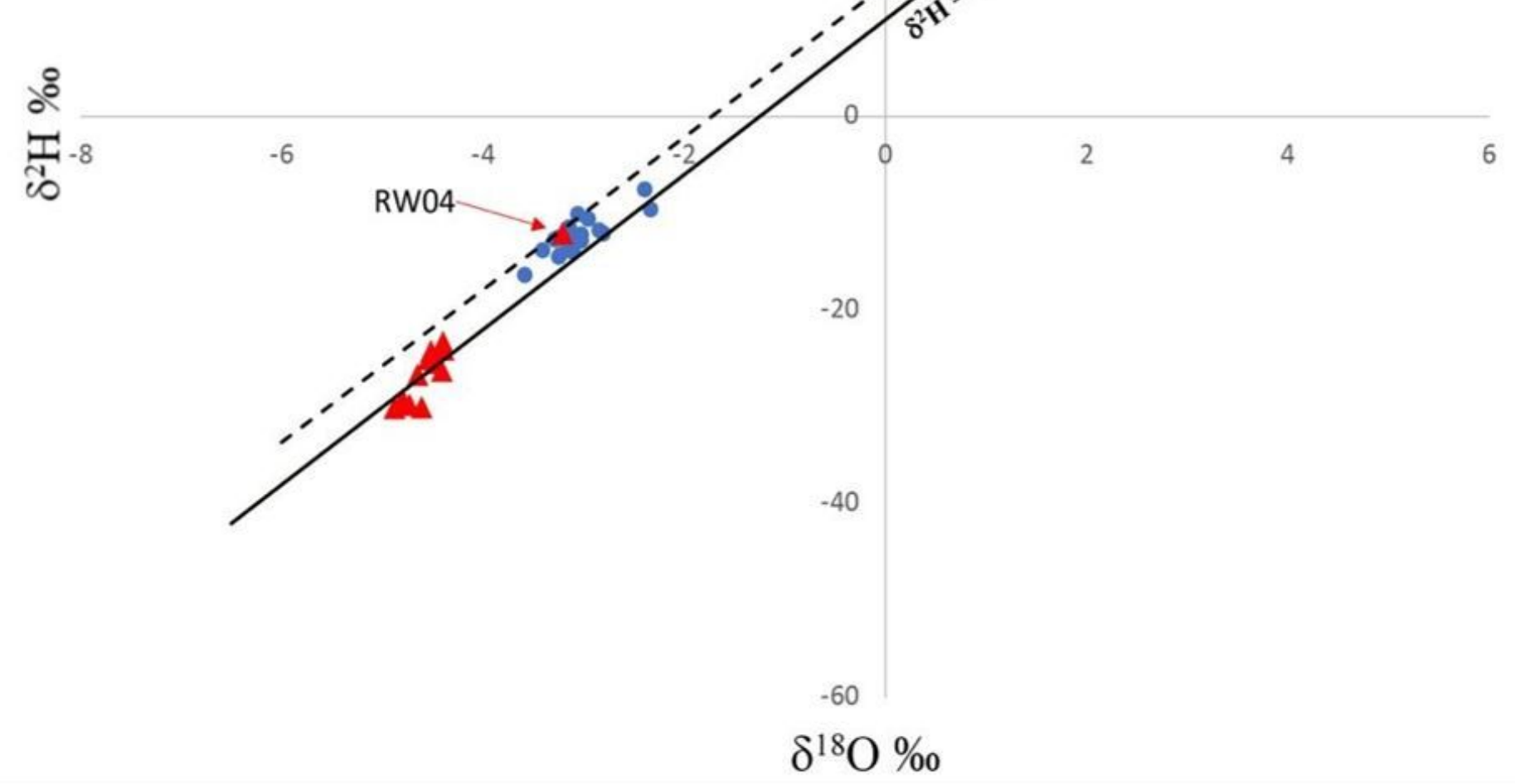

\section{Figure 7}

A scatter diagram of $\delta^{2} \mathrm{H}-\delta^{18} \mathrm{O}$ of the samples analysed in this study. Also shown are the GWML, LWML and LE 

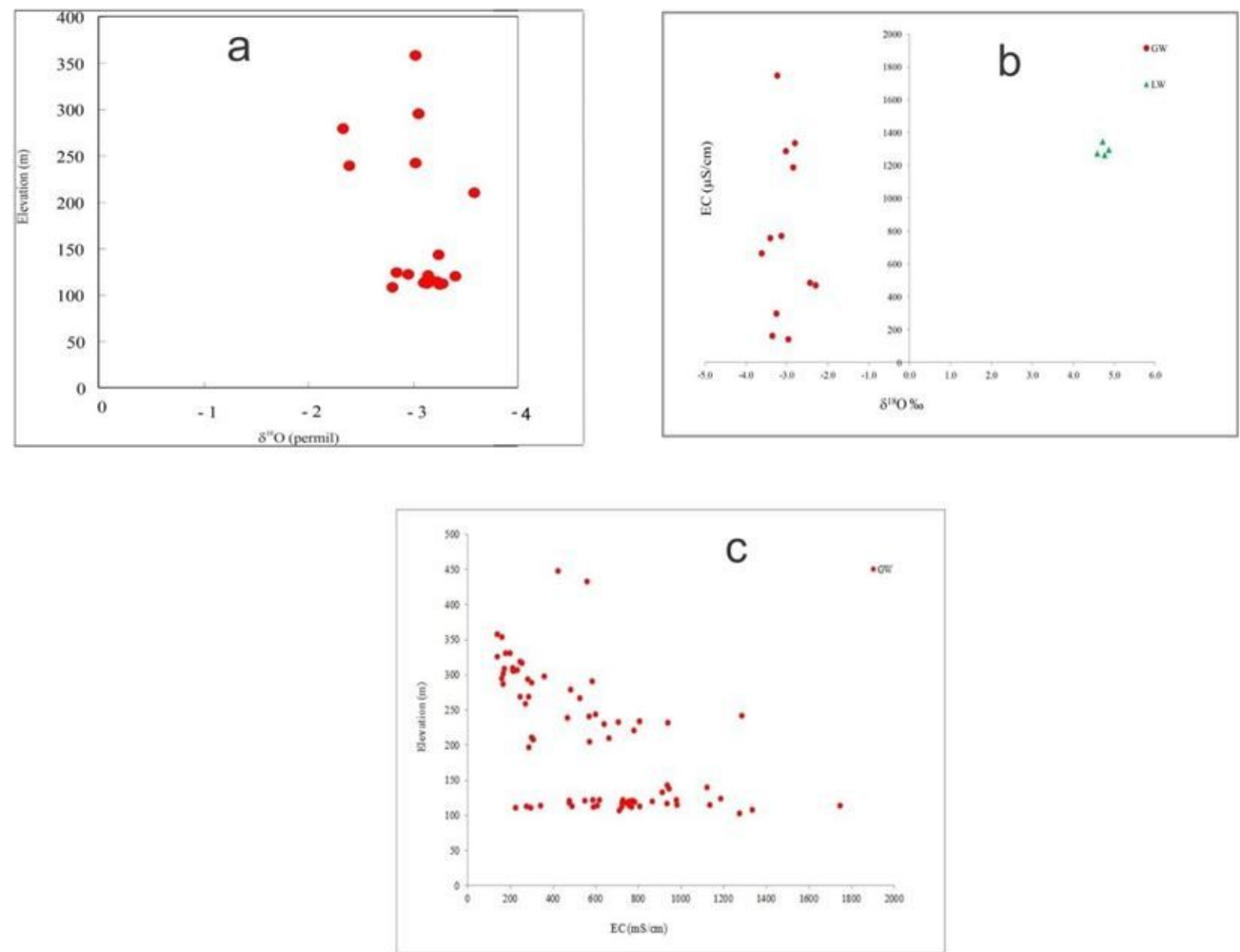

Figure 8

$\mathrm{a}, \mathrm{b}$ and $\mathrm{c}$ : Relationship between EC and $\delta^{18} \mathrm{O}$ for the groundwater and lake water, relationship between Elevation and $\delta^{18} \mathrm{O}$ for the groundwater and relationship between Elevation and EC for the groundwater 